\title{
Youth ministry at the margins and/or centre as space of the other: Reflections on the resolutions of the Anglican dioceses in the Western Cape 2017
}

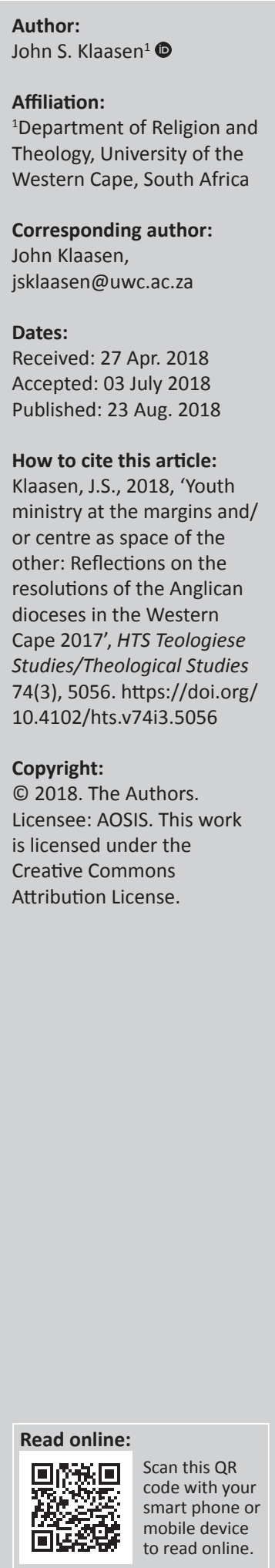

Youth within the context of faith-based organisations carry with them certain power relations and misconstrued connotations. These power relations and connotations can contribute to alienation and marginalisation. The resolutions taken at the recent synods of the three dioceses within the Western Cape reflect and identify the areas - both liturgical and governance - of marginalisation of youth within the Anglican Church in southern Africa. The resolutions also call on the church governing bodies and the leaders to create safe spaces for the youth to be a central part of the mission of the church. Areas such as liturgy, training and formation, contemporary worship and nurturing relationships are identified within the resolutions. Theological notions of personhood within the Anglican tradition are to be investigated as possible motivations for more acceptable power relations of the youth and leaders and governance structures. What implications do such theological formulations have for the space that the youth occupy within the margins of the church? A critical reflection of the synod resolutions answers such questions and points to some contours for sense making of the youth within the margins of the church from a faith-based organisational perspective.

\section{Introduction}

Youth within the context of the church carry with them certain power relations and misconstrued connotations. These power relations and connotations can contribute to alienation and marginalisation. Faith-based organisations, as phenomena that are harbingers of spaces for nurturing formation and transformation, have not always contributed towards empowering youth at the margins.

The youth occupy a traditional marginal position in the church. The church's centre is made up of decision-making bodies. These, whether they are local or diocesan, are dominated by ordination. Because very few of the youth are part of the ordained ministry, and subsequently part of the decision-making bodies, there is a clear divide between decision-makers at the centre and the youth at the margins.

The two distinct positions - centre and margins - represent the space(s) of power and powerlessness within the church. The centre is the space for decision-making with regard to church operations like administration, ministry, worship and formation. The margins, or the space occupied by 'the other', are the receptors of administration, ministry, worship and formation. The youth are part of those at the margins. This is clearly demonstrated in the recent diocesan resolutions of the three Anglican dioceses in the Western Cape, namely The Diocese of False Bay, The Diocese of Saldanha Bay and The Diocese of Cape Town.

This research will analyse the resolutions that concern the youth of the three dioceses and how they address the incorporation of the youth at the centre. The analysis will assess whether the diocesan synod identifies the position of the youth in relation to decision-making and ministerial formation in the church. How is the youth perceived with regard to structures and organisations of power? In other words, does the youth have a significant voice in the legislative bodies and formation processes influencing the mission of the church, and what measures are needed to draw the youth to the centre?

Another question that will be asked is whether the centre as spaces of power is exclusively demarcated as the existing decision-making bodies and ministerial formative processes. This question contrasts the former question and critically engages with the traditional spaces as exclusive 
spaces of power. In other words, are the traditional structures and legislative bodies the only centres of power? Is it possible that drawing the youth into the existing centres can cause alienation, co-option, coercion or condemnation? The author will draw on the missional approach to illustrate how the youth and youth ministry are an integral part of the mission of the church.

\section{Youth at the margins or centre}

Youth as a population group has diverse meanings. In some parts of the world, youth is associated with an age category and can be surpassed by transcending a particular age. In some cultures, youth is merely a stage of life and is transcended through rituals or cultural processes. Within certain cultural and population groups initiation rituals transform a young child to youth, and then again from youth into adulthood. Youth is regarded as those between the ages of 13 and 35 years.

By 2010, half of the world's population was under the age of 25 , and in some countries this percentage increased to $75 \%$. It is estimated that by $2025,23 \%$ of the world's population will be considered as youths, which will be:

one of the largest generations in history. Despite its size, it is not an economically powerful group. More than half of the youth of the world survive on less than $\$ 2$ a day ... So it's no wonder that corporations, church and mission groups, colleges and seminaries, service agencies, parents and governments increasingly focus on children, youth, and the concerns of adolescents. (Linhart \& Livermore 2011:29)

The resolutions taken at the recent synods of the three said dioceses reflect and identify both areas of marginalisation liturgical and governance - of youth within the Anglican Church in southern Africa. The preamble of the motion at the Diocesan Synod 2017 of The Diocese of Cape Town states that:

Young people of all ages are our present and future church and it is critical for those who are involved in the leading and teaching of our young people to receive adequate training and support.

It also states that 'The vast majority of parishes struggle to access or fund resources required for a vibrant Youth Ministry' and 'Our diversity makes a "one size fits all" curriculum and strategy unworkable' (Lavarello-Smith \& Foflonker 2017:1-2). This shows that young people are deprived of adequate training, support, resources and relevant strategies for effective ministry. Within the context of the church's deprivation of these indispensable ministry tools, groups such as the youth are relocated to the periphery.

Yet, when compared to the aforementioned, the Diocese of False Bay has even gone a step further when the bishop in her address to the synod, under the rubric 'Youth', asserted that the church will seek:

To raise our voices for Rights awareness, to create an awareness of the social, economic and spiritual dangers and to empower youth to raise their voices against the oppression and brutal abuse of their peers. The bishop also called on the church governing bodies and the leaders to create safe spaces for the youth to be a central part of the mission of the church. Areas such as liturgy, training and formation, contemporary worship and nurturing relationships are identified within the resolutions. (Vertue 2014:24)

This indicates that these areas have been identified in the previous synod of 2014.

Both preambles imply that the youth are occupying a space that has no power and is outside of the primary ministry of the congregation. Nowhere is it stated that the church will take the responsibility to transform the marginalisation of the youth. Creating awareness of options does not translate into change unless awareness and choices are accompanied by taking responsibility. The youth are at the margins and separated from the decision-making bodies. The margins are subordinate to the dominant cultural and traditional practices. These cultural and traditional practices are identified with the older generation who controls the power relations. In a number of Anglican churches, the youth ministry is separated from the mainstream and principal worship services. Even in churches where youth ministry flourishes, the congregation perpetuates separation by insisting on ministry based on a generational basis. Cloete's (2015) assertion in this regard has direct meaning for the Anglican youth ministry:

In the context of increased separation between the youth and adults, age-specific ministry developed, where specialised ministries were offered to different age groups. Age specific ministry seems to be one of the main reasons why youth ministry developed into separate ministry, segregated and isolated from the congregational ministry. (p. 3)

Although the difference between the young persons and older people in congregations is a common phenomenon, it does not mean that separation is justifiable. Margaret Mead, the founder of the generational theory in sociology, identified three generations while observing the people of Papua New Guinea over a period of five decades. Firstly, there was the generation who assumed that children will be socialised with the same values as the older people. Secondly, there was the generation who assumed that the behaviour of children would naturally differ from that of the older people. And thirdly, there was the generation consisting of two distinct groups with the youth setting the trends of behaviour and patterns of society. The youth are different in both substance and purpose. Their value system is different from that of older persons and their habits are not identifiable with the past (Codrington \& Grant-Marshall 2005:14-15).

Generational differences have been used to justify the position of the youth. The difference in age, practices, customs, habits and value systems are reasons for the marginalisation of the youth in the church. While differences between the generations are inevitable, it does not have to amount to separation. Separate ministry, structures and processes do not necessarily contribute to effective and holistic ministerial formation of the youth. It is useful to draw on the distinction that Derrida 
makes between 'differance' and 'difference'. The former refers to a clear distinction, an unequal relationship between two phenomena but with the equally important delay in space and time that covers the potential that can be fulfilled. In this sense, there is room for expansion as transcendence of the incomplete and final form. There is the possibility to transcend the present limits. On the contrary, 'difference' refers to two or more entities that are separated with very little in common (Inac \& Unal 2013:223). This distinction resonates with Cochrane's assertion that the imago Dei means that human beings are figured but not depleted (logos) and the predetermined is not fully comprehended (myth) (2009:16-17). The youth are not immune to the culture of the older generation. There is always potential to transcend the blurred barriers that define the culture and engage with the other as creative other. Cochrane (2009:16-17) refers to the momentary dissociation of the self as 'slippage in the self between conscious and the unconscious and ... the equally pertinent slippage in the relationship of the self to the other'.

The youth at the margins does not discount the power that it possesses to make a transformative contribution to the youth in general and other generations that share the spaces with it even if it is only momentarily. These moments of crossing over or blurring of boundaries signify the creative interaction that enables two independent variables to form an interactionist influence on each other. This kind of interaction leads to tension that absorbs the difference into a continuous whole. This creative tension does not lead to separation, but to newfound possibilities. Cloete (2015) defines creative tension as:

a product or result of the interrelatedness and connectedness of ministry as a complex system. These two seemingly opposite positions keep the tension intact and create energy for creative innovation through ministry. Therefore the ideal seems not to release the tension, but rather to keep it in tact and let it work for something greater and better than the current reality. (p. 2)

The margins as well as the centre are not immune to diversity. The margins are not restricted to a certain generation or group of people. It is the place where God dwells. Gregory Boyle S.J., an ordained priest who spent most of his ministry serving at-risk youth, asserts that people are created to walk alongside others and that especially those at the margins is part of God's family. God vision is not for people to do the right thing but to be in the right place. The right place is at the margins where those who feel marginalised is part of the family of God (2010:382).

The margins - the space occupied by the youth in the church are more a location than an identity. It is a place of diversity where people are formed in a common response to the needs of others. The margins are not an exclusive and private space for a specific authority, but are the place of form, forming and formation. People are drawn to the place by kinship and community and not selfish, atomistic interest. The margins are a space where boundaries become increasingly blurred by the mutually enriching offerings of those who recognise the potentialities in the constructive other.
How do the margins and the centre interlink? Put differently, how do the youth share in the legislative and ministerial power of the church without surrendering their cultural uniqueness? A more inward looking issue is: what connects the diversity within the margins? The relationship is not only between the margins and the centre but also within the margins. In the first instance, the two generations are connected by a common belief system, and in the second instance, the commonality is more cultural than religious. The author contends that the link between the margins and the centre and within the margin must be a single thread. The author will now explore the possible relationships between a missional approach and youth ministry.

\section{Missional approach and the margins}

Clark (2001:80) defines the missional approach 'as the community of faith corporately committed to caring for and reaching out into the adolescent world (of both churched and unchurched young people) in order to meaningfully assimilate them into their fellowship'. This approach resonates with the Lambeth Conference ${ }^{1}$ of 1988 and the new notion of ministry that is mission orientated: 'Since Lambeth 1988 a new model emerged which fully recognises the gifts of the "lagos" and encourages the full participation of the whole body of Christ in ministry'. Avis, a prominent Anglican theologian, terms this the 'communion-through-baptism model' of which baptism, and not confirmation or ordination, is 'at the centre of our inclusion into the messianic office of Christ as Priest, Prophet and King. This enables Anglicans to perform the prophetic and royal functions' (Klaasen 2012:50).

This shift in the Anglican Church had serious implications for the power relations and pillars of power within the church. Prior to this shift, the ministerial and legislative power was solely in the hands of the ordained and, to a lesser extent, in the domain of the laity. It is clear from the 2012 resolution and the subsequent 2015 resolution of the Diocese of Saldanha Bay that the youth was excluded from the centre of power. In his notes from the synod of 2015, Reverend Chris Ahrends, Canon Missioner from the Diocese of Saldanha Bay, wrote under the heading 'Mission priority: Youth ministry Developing and retaining young people in the church':

This resolution, passed unanimously, resolved to keep our YOUTH MINISTRY as a priority mission area within the life of the Diocese; enabling them to attend diocesan meetings; setting aside funds at diocesan and parish level to support training; keeping June each year as a special Youth Month; supporting ONE special collection throughout the Diocese in support of youth ministry; ensuring youth representivity throughout the Diocese and creating ONE super structure in the Diocese under which ALL activity will be coordinated. All parish councils really should spend time reading and digesting this resolution! (2015:2)

The resolution describes both the distance between the margins and the centre, and the intention to address the issue

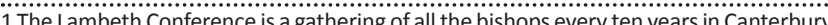
Although this is not a legislative body it is the largest and most influential gathering Although this is not a legislative body, it is the largest and most influential gathering of the worldwide Anglican Communion. It passes motions for communion throughout the worldwide Anglican Church. The 1988 Lambeth Conference was in August. The next Lambeth Conference is in September 2018. 
of the representation of the youth (or rather lack thereof) in the legislative and decision-making bodies of the church. This representation raises the extent of the positioning of the youth in the centre. Nowhere is there an indication that the youth will form part of the centre with regard to ministerial formation. There is no real commitment to bring the youth within the centre of the ministry of the congregation. The youth remains separated from the rest of the congregation. This approach is still generationally modelled.

The missional approach to youth ministry considers the culture or subculture of the youth and accepts that youth is a definitive stage in the lifespan of people. The ministry therefore must encompass the youth, and the uniqueness of the youth must form part of the ministerial formation processes. The missional approach regards the older generation 'as missionaries and adolescents as a people to be reached with the gospel of Jesus Christ. Principles that guide cross-cultural ministries around the world apply to youth ministry' (Clark 2001:80). Ward (2015) concludes that:

a growing concern for multicultural organisations, both in the church and in the business world, is that of dealing better with stereotyped prejudices and underlying biases. The need for tolerance, a better understanding of cultural differences, and empathy is seen as a key factor in groups that wish to continue in the global village. (pp. 173-174)

The missional approach can be misconstrued as a 'we' and 'they' designation, with the 'we' group occupying the centre and the 'they' group the margins. This misconstrued notion of the church community results in the older generation perceiving the youth as that part of the world that is in need of mission. This misconception does not take cognisance of the centrality of youth ministry for both the church and the world. It is for pragmatic reasons that youth ministry is given priority in the three Anglican dioceses. There is no theological or ecclesiological motivation given for youth ministry. The basis of youth ministry is to grow the ministry for pragmatic reasons by providing resources and representation in decision-making bodies. This is programme-oriented and coupled with the overarching structures; it is a controlling mechanism. Instead of drawing the youth into the centre, youth ministry is separated from the primary functions of the church. The resolution of the Diocese of the Saldanha Bay went so far as to resolve to macro manage the youth under 'ONE super structure in the Diocese' (Ahrends 2015:2).

Within the missional approach, the church moves beyond the borders of its own members to the broader societal membership. Clark (2001) asserts that:

missional youth ministry will contain elements of community, but never for the community's sake ... The goal is not to simply focus on those who already are involved in a given church's youth ministry program. The theologically driven missional mandate of youth ministry is to bring the gospel and the kingdom to every adolescent. The church must step up and allow this theological axiom to shape and alter ecclesiological traditions and norms. (p. 81)
Youth ministry that is modelled around a missional approach raises important issues such as the relationship between the church and the secular. How does the church relate to the youth that are outside of the traditions and norms of the church? This relationship can also take on a centre and margins approach. The church is the centre, and for the margins to have any meaning, they must become part of the centre. Becoming part means taking on beliefs, norms and practices that might be completely foreign to those from a secular background. On the contrary, the church might take a greater interest in the traditions and norms of the secular in order to appreciate the secular as an interactionist partner in the missio Dei. The missional approach to youth ministry is more concerned with the extent to which the church is a nurturing and safe environment for the youth, and youth ministry extends that concern as part of the mission of the church. Youth ministry must engage and seek to understand the secular in order to carry out effective mission to the youth beyond the borders of the church.

The missional approach to youth ministry lies within the theological notion of the missio Dei with the two 'performative mission-movements'. The first was to safeguard the confessional church, creedal formulations and dogmatic truths within the global society. This movement is characterised by clerical power, canon law and policy, and is known as the 'movement inside'. The second movement, the 'movement outside,' was concerned with evangelising those outside of the church. This movement was closely connected to the diaconal ministry of the church. Hospitals, schools, employment, medical supplies, food supplies and other kinds of development efforts were attempts to convert people to Christianity (Louw 2016:340-341).

A missional approach to youth ministry seeks to draw the youth within the ministerial processes of the church. While the church - those at the centre - provides resources for youth ministry, the power remains within the centre. On the contrary, interaction with secular youths is from a position of power and with a predetermined goal of conversion.

The three resolutions on youth ministry from the said dioceses highlight the position occupied by the youth in the church. The youth is positioned at the margins. All three resolutions identify youth ministry as separated from the mission of the church. Youth ministry is programme-oriented, and its goal is to retain the youth for as long as possible. The role of the church towards the youth is to give them representation in the decision-making bodies. It is not clear whether representation is in proportion to other generations and whether representation is tokenism. While the dioceses are commended for their resolutions and willingness to address youth as an important ministry, two fundamental issues remain to be resolved: firstly, the identity of the youth, and secondly, the position of youth ministry in relation to the mission of God. These issues were not addressed in the resolutions. The author will now assert that if the church does not address the theological and ecclesiological 
assumptions of the identity of youth and youth ministry, then the youth will remain powerless in the church.

\section{Youth and personhood}

Religious and social understandings of what it means to be a person can be misconstrued as formations of individuals that develop within closed systems. Notions of who we are in relation to the centre and the margins of a faith-based organisation, such as the church, need critical engagement to assess the role of faith-based organisations to empower the youth.

Theological notions of personhood within the Anglican tradition need to be investigated as possible motivations for more acceptable power relations among the youth, leaders and governance structures. What implications do such theological formulations have for the space that the youth occupies within the margins of the church? Critically reflecting on the synod's resolutions will help answer such questions from a faith-based organisational perspective and provide contours for meaning-making concerning the youth at the margins.

Youth as a different generation has a unique culture or at least subculture in comparison to or vis-à-vis the older generation. The older generation occupies the centre and, subsequently, the position of clerical, polity and ministerial dominance. The author will now apply the notion of personhood to effective youth ministry. The author will also seek to demonstrate by means of the theological notion of personhood as identity that the youth, although at the margins, are not powerless. This theological notion poses a challenge to the ecclesiological understanding of the Anglican Church in southern Africa. Revisiting the theological notion of personhood creates the starting point for critical reflection on the recent resolutions of the three dioceses in the Western Cape concerning youth ministry.

A theoretical description of identity is very complex and diverse. Wetherell (2009) asserts that:

familiar social class hierarchies have been replaced with multiple, fragmented and more uncertain projects ... Are 'liquid' 'senses' of self, and volatile and dynamic forms of identity politics, becoming more salient ... In social and psychological theory, the term 'identity' is itself the locus of controversy - what is its value and currency? It seems to suggest illusory fixity, it seems to separate the social from the personal ... (p. 1)

Despite the complexity and diversity of the conceptual analysis of identity, identity has become an indispensable variable in both the soft and hard sciences. The theology of identity lies at the heart of 'who we are' in relation to God, others and the rest of creation. The current political and social landscape of South Africa with the unprecedented youth unemployment rate, as well as the recent student uprising coupled with the challenges that the youth present to the church authorities, is intertwined with the theological notion of personhood. Boyle (2010) claims that:
When you stand at the margin the hope is to preach in and dismantle the message of shame and disgrace and replace it with something else: the truth. Alice Miller, the child psychologist, calls it choosing to become enlightened witnesses, people who through their kindness and tenderness, and attempt to love, return people to themselves ... Here is the truth of who you are and it happens to your truth as well. You are exactly what God had in mind when God made you; and then you watch the poor and the folks on the margin and the culturally despaired become that truth and having that truth and nothing is the same again'. (p. 385)

The identity of the youth is rooted in the nature of God and the relationship of the self with other selves. Anglican identity is founded on the Trinitarian God. The Trinity is epistemologically situated on two historical developments. The first development was response of the Cappadocian Fathers - Basil the Great, bishop of Caesarea, (329-379), Gregory of Nyssa (335-394) and Gregory Nazianzus (329-390) - to the Arian controversy. The Early Church Fathers conceptualised the Trinity as three hypostases. This means that the Trinity is an inseparable relation between Father, Son and Holy Spirit. The main point is that Father, Son and Holy Spirit are one in communion. One can speak of the one single universal and its particulars. The persons are also distinct with stories, speech and actions, which allows them to respond and also to be open to response. This amounts to a relationality of the Trinity. The Trinity, according to the Cappadocian Fathers, strengthened the relationality of the Trinity by making the distinction between person and individual. The latter is determined by its degree of independence, while the former is characterised by relations with others (Klaasen 2013:186-187).

The second historical development lies in the explanation of the Trinity as unity in diversity as further explained by John of Damascus by using the term 'perichoresis' as the reciprocal offering and accepting of the free communion between Father, Son and Holy Spirit. The existence of the person is not the degree of self-existence but the measure of voluntary invitation (Klaasen 2013:187).

The theological notion of the Trinity that is underscored by the Cappadocian Fathers and John of Damascus makes two important observations in relation to youth and youth ministry. Firstly, young people are persons in relation. Young people, created in the image of God, are persons who relate with God and other human beings. Within the church context, young people are created in God's image as they relate with other persons in mutually enriching relationships.

Young people are social beings who exist in and through relationships. The Enlightenment project of autonomous individuals has come under serious scrutiny because of the move away from interdependency to autonomy. The Enlightenment project describes a self as an independent, dissociated being. The Trinitarian formulation emphasises the relationality of God as found in the Trinity and between God and persons. Young people, although at the margins, 
possess the innate characteristics of enriching other persons and being enriched by other persons in turn.

When the youth is treated like a group of individuals or a collection of individuals, then the margins become a space of alienation, coercion and domination. The centre has the kind of power that does not empower or enrich mutually, but that excludes to control and ultimately separates.

Secondly, young people's ministry is not separated from the mission of the church. Ministry to young people challenges the attempts of the church to exclude youth ministry from the mission of the church. The resolutions clearly indicate that youth ministry is not part of the primary ministry of the church, but it is added on as a secondary ministry. Youth ministry should be part of the mission of the church and should enjoy the same dedication and commitment as the mission of the centre. The margins and the centre are part of one continuum. This continuum is situated within the ecclesia. The church is a place that has both a centre and a margin, without regarding one as inferior to the other. There is difference of culture, practice, habits and modalities of communication. This does not mean that the different spaces are separated or divided into unequal power relations. The ecclesia 'is possessed by a vision of God and the created order as open and engaged in a life-process. Unity is not to be equated with the denial of difference or the reduction of them all in one, but speaks of the mutual intercommunion and interpenetration of elements of difference' (Greenwood 1994:88).

Youth ministry is about God's interaction with persons. It is not about positions, power or punishment, but about God's salvation plan for humankind, especially for the youth who is an integral part of the ecclesia. Youth ministry is a response to the activity of God among all people, but in particular the people at the margins:

Jesus is standing in the lowly place and he invites, he beckons, he asks us to join him. Jesus was a man of equal opportunities and he pissed off a lot of people because he did not respect their purity codes. He associated with the wrong people: He shared table fellowship with sinners, he talked to lepers even before healing them ... What were you doing there with those people in the lowly place at the margins? (Boyle 2010:384)

Youth ministry at the margins is precisely where Jesus meets the youth and offers transformation. Youth ministry is powerful not when it is given representation on boards and committees, but when it is part of the mission of the church. When youth ministry is regarded and supported with the same commitment as other ministries and with the same status in relation to the mission of the church, then the margins are the dwelling place of the Risen Lord.

\section{Conclusion}

The resolutions on youth and youth ministry offered by the three Anglican dioceses in the Western Cape are an attempt to highlight the shortcomings in the youth ministry in the
Anglican Church in the region. The resolutions acknowledge the need for more resources, adequate space, funds, the need for creating awareness of the rights of the youths, financial support and representivity in decision-making bodies. However, the resolutions neglect the value of the margins that the youth occupies. The space that the youth occupies is misconstrued as powerless and not effective for missionary endeavours. A missional approach to youth ministry seeks to place the youth and youth ministry within the missio Dei and, subsequently, the mission of the church. The missional approach locates the margins in continuum with the centre, and the boundaries are blurred so that overlap connects the margins and the centre in an interactionist relationship. The theological basis for the indispensability of youth ministry for the mission of the church is found on the response of the Cappadocian Fathers to the Arian controversy and John of Damascus' perichoresis. Young people are created in God's image and are situated in the Trinitarian God. Youth ministry takes place at the margins where Jesus invites the church to respond to the mission of God. Youth ministry is part of the congregational ministry and is intergenerational. The neglect of the identity of the youth is a common weakness in the resolutions of all three dioceses, and therefore, the missional youth ministry approach that I propose in this article could make a significant contribution to the youth and youth ministry of the Anglican Church.

\section{Acknowledgements Competing interests}

The author declares that he has no financial or personal relationships which may have inappropriately influenced him in writing this article.

\section{References}

Ahrends, C., 2015, 'The Diocese of Saldanha Bay The Anglican Church of Southern Africa (CSA)', Notes from synod 2015 in terms of the resolution taken at Synod that within two weeks of Synod, a summary of the Resolutions passed at Synod 2015 be circulated to all within the Diocese! (unpublished).

Boyle, G.J. 2010, 'The challenge of serving a diverse church: Being Christ for others', Catholic Education: A Journal of Inquiry and Practice 13(3), 380-391.

Clark, C., 2001, 'The missional approach to youth ministry', in M.H. Senter III (ed.) Four views of youth ministry and the church; Inclusive, preparatory, missional and strategic, pp. 77-96, Zondervan, Grand Rapids, MI.

Cloete, A., 2015, 'Creative tensions in youth ministry in a congregational context,' HTS Teologiese Studies/Theological Studies 71(2), 1-7. https://doi.org/10.4102/hts. v71i2.2107

Cochrane, J.R., 2009, 'On identity and faith in the global political economy,' Journal of Theology for Southern Africa 134, 14-31.

Codrington, G. \& Grant-Marshall, S., 2005, Mind the gap! Penguin Books, Johannesburg.

Greenwood, R., 1994, Transforming priesthood: A new theology of mission and ministry, SPCK, London.

Inac, H. \& Unal, F., 2013, 'The construction of identity in modern times: Theoretical perspective', International Journal of Humanities and Social Science 3(11) 223-232.

Klaasen, J., 2012, 'Ministerial formation in the Anglican Church of Southern Africa', in M. Naidoo (ed.), Between the real and the ideal: Ministerial formation in South African churches, pp. 48-62, Unisa Press, Pretoria.

Klaasen, J., 2013, 'The interplay between theology and development: How theology can be related to development in post-modern society', Missionalia 41(2), 82-95.

Lavarello-Smith, L. \& Foflonker, S., 2017, Motion to be considered before the Diocesan Synod August 2017 (unpublished).

Linhart, T. \& Livermore, D., 2011, Global youth ministry: Reaching adolescents around the world, Grand Rapids, MI. 
Louw, D.J., 2016, 'Missio Dei as embodiment of Passio Dei: The role of God-images in the Mission-outreach and pastoral caregiving of the church - a hermeneutical approach', Missionalia: Southern African Journal of Missiology 44(3), 336-354.

Vertue, M., 2014, Bishop's Charge to the 2014 Synod of the Diocese of False Bay (3rd Session), 'The Abundance of the Holy Spirit', 24-26 February, Parish Church of St. George the Martyr, Kuils River.
Ward, 2015, 'Cultural diversity in sickness and healing: The domain of caring S.A.', in K. Federschmidt \& D.J. Louw (eds.), Intercultural and interreligious pastora caregiving, pp. 173-180, Books on Demand, Norderstedt.

Wetherell, M., 2009, 'Introduction: Negotiating liveable lives - Identity in contemporary Britain', in $\mathrm{M}$. Wetherell (ed.), Identity in the 21st century: New trends in changing times, Identity Studies in The Social Sciences, pp. 1-18, Palgrave Macmillan, Hampshire. 